\title{
Exploring Sex Differences in Attitudes Towards the Descriptive and Substantive Representation of Women
}

Forthcoming in the British Journal of Politics and International Relations

Final accepted version - 25 July 2016

Peter Allen - Queen Mary University of London, p.allen@qmul.ac.uk

David Cutts - University of Bath, d.j.cutts@ bath.ac.uk

Academic discussions about the political (under-)representation of women tend to focus on descriptive or substantive representation - that is, the numbers of women present in politics or the representation of so-called 'women's interests' in politics. As such, arguments in favour of increases in women's representation tend to invoke either or both of these ideas. Many, for example, argue that an increase in the descriptive representation of women (DRW) may result in an equivalent, or related, increased in the substantive representation of women (SRW) (Pitkin 1973; Lovenduski 2005; Mackay 2008), although the intricacies of what this may actually consist of are contested (Celis et al. 2008). Alternatively, the argument from justice articulates that a descriptive increase is desirable regardless of any resultant impact on substantive representation (Phillips 1995). Similarly, other arguments in favour of increased descriptive representation claim that such an increase will positively affect women, and other under-represented groups, in a symbolic way (Mansbridge 1999; Phillips 2012). As such, there are arguments that focus on substantive political outcomes as a result of any increase in the number of women in political institutions, and those that do not. 
Despite this extensive literature, including multiple pieces of research focused on levels of public support for different measures designed to increase the number of women in politics, or the wider impact of these, we understand little of the public's reasons for supporting such an increase (Alexander 2012; Broockman 2014; Clayton 2014). In this paper, we seek to redress this imbalance in the literature. Where public support for an increase in the number of women in politics exists, we look to find out whether it is driven by the anticipated gains in substantive representation it will bring about, or do the public instead support an increase for other reasons, without primary regard for any subsequent policy outcomes that can be considered as better representing 'women's interests'.

In this paper we use data from the 2015 Northern Ireland General Election Survey to unpack public opinion on women's political representation for the first time in the UK literature. We distinguish between those who support increases in descriptive representation and believe that women are better at representing women's interests than men (a DRW-SRW link) and those who support descriptive increases without holding such a belief, a kind of support we

refer to as 'justice-plus'. Our key finding suggests that women were significantly more likely than men to both believe that an increase in DRW was necessary and that such an increase would enhance the representation of women's political interests (SRW). In contrast, men were significantly more likely to support an increase in DRW but not relate DRW to SRW the justice-plus rationale.

\section{Why support an increase in the descriptive representation of women?}

There is a substantial theoretical literature that describes the likely, anticipated, or desired effects of having more women in political office (Pitkin 1973; Dahlerup 1988; Phillips 1995; Mansbridge 1999; Young 2001; Lovenduski 2005). For a long time, this literature was 
theoretical out of necessity thanks to the small numbers of women who were elected to legislatures worldwide. More recently, though, this theoretical literature has been supplemented by an empirical literature assessing what the impact of the welcome and overdue increase in the numbers of women in politics has actually been (Vega and Firestone 1995; Childs 2004; Lovenduski \& Norris 2003; Cowell-Meyers and Langbein 2009; Murray 2010; Allen et al. 2015).

Across the literature, we can find two broad rationales for why someone might wish to support an increase in the number of women in politics. ${ }^{1}$ First, you might want to have more women in political office because you believe it will result in the better representation of women's interests, subjectively defined, in the form of what you take to be preferable political outcomes for women. That is, you feel that there is a link between an increase in the DRW and the subsequent SRW. Second, you might support an increase in the DRW in political office because to do so is the just thing to do, regardless of what happens as a result, or because of other anticipated effects not related to the actual representation of women's interests. These effects might include a kind of symbolic representation, or other unintended wider benefits of having more women in office. Anne Phillips neatly summarises this distinction, writing 'I think that the issues we have addressed in recent years under the rubric of representation are not all, or not always, about that. They are often more about inclusion than representation, more about what it means to be recognized as a full member of one's

\footnotetext{
${ }^{1}$ To be clear, we assume throughout that such an increase is in pursuit of parity with the number of men holding political office. Although our arguments and findings may hold in a situation where women are a majority of political office-holders, we do not have the data to test our ideas in such a situation.
} 
society than how one can effect policy change' (2012, p.517). We refer to these different positions as the substantive and justice-plus rationales and briefly summarise them below. ${ }^{2}$

Writing about those who see a link between DRW and SRW, Celis et al. note that 'the core assumption is that 'numbers matter': an increase in women's descriptive representation in parliaments will generally - even automatically — translate into an increase in SRW' (2008, p.99). This idea has informed a substantial body of feminist research into whether or not men and women differ in focus or behaviour once elected to political institutions (Thomas and Welch 1991; Swers 1998; Reingold 2000; Carroll 2001; Childs 2004). Contemporary accounts of this possible link between increased DRW and some kind of equivalent increase in SRW have problematized the notion of 'women's interests' itself (Celis et al. 2008; Childs and Krook 2009; Celis and Childs 2012). In particular, Celis and Childs have noted that the previous approach of academics asking whether such a link between DRW and SRW existed consisted largely of 'counting the number of women present in a particular political institution and judging the actions of women representatives against a 'feminist' shopping list of demands' (2012, p.213). As such, the idea that 'women's interests' exist in an objective sense has been brought into question, consequently complicating the link between DRW and SRW.

For our purposes in this paper, though, such academic debates are not so relevant. The popular discourse that surrounds the activities of politicians suggests that the public themselves still strongly believe in a link between the characteristics held by a politician and how they are likely to act. Popular conceptions of the 'political class', for example, rely

2 We thank one of the anonymous reviewers for the observation that these categories could apply to any group that is traditionally under-represented in politics, such as ethnic minorities, individuals with disabilities, and LGBT communities. 
heavily on the fact that politicians are not descriptively representative of the voters at large in terms of socio-economic class and that this results in some deficit of representation on economic issues (Hacker and Pierson 2011; Carnes 2013; Allen and Cairney 2015). Similarly, debates around issues that would be at the heart of any conception of a link between DRW and SRW, such as abortion, have at their core the notion that women will see these issues differently to men (Bicquelet et al. 2012; Penny 2015). In 2012, President Obama weighed in on comments made by an Indiana Senate candidate regarding abortion in cases of rape, saying 'this is exactly why you don't want a bunch of politicians, mostly male, making decisions about women's health care decisions'. ${ }^{3}$ Given the nature of the popular debate on the issue, it stands to reason that the public might well have an intuitive folk belief in some kind of link between descriptive and substantive representation.

The justice-plus rationale for increasing women's descriptive representation starts from Anne Phillips' famous argument from justice. She writes (1995, p.65):

What we can more usefully do is turn the argument around, and ask by what 'natural' superiority of talent or experience men could claim a right to dominate assemblies? The burden of proof then shifts to the men, who would have to establish either some genetic distinction which makes them better at understanding problems and taking decisions, or some more socially derived advantage which enhances their political skills. Neither of these looks particularly persuasive; the first has never been successfully established, and the second is no justification if it depends on structures of discrimination. There is no argument from justice that can defend the current state

\footnotetext{
3 http://politicalticker.blogs.cnn.com/2012/10/24/obama-on-mourdock-male-politiciansshouldnt-make-abortion-decisions/
} 
of affairs; and in this more negative sense, there is an argument from justice for parity between women and men.

Crucially, Phillips' argument is not reliant on what might come about as a result of their being more women in political office. It does not assume that such an increase will result in any particular policies or political outcomes that might benefit women. There are other arguments that equally do not rely on SRW of any kind to justify any increase in DRW. For example, Jane Mansbridge (1999) outlines the ways in which the increased descriptive representation of any social group that has traditionally been politically under-represented might result in various symbolic benefits for members of that group. These include an increased belief in their own ability to rule and participate in politics, as well as the increased legitimation of the political institution in question in the eyes of the traditionally underrepresented group. In other words, women are deemed likely to see a descriptive increase in women in politics as a sign that women as a group do have a role to play in decision-making political institutions, and to see the decisions emanating from those institutions as more legitimate as a result of women's increased presence in them (Mansbridge 1999).

\section{Hypotheses}

Our interest in this paper is threefold. First, we look to establish overall levels of support for an increase in the descriptive representation of women in political legislatures, and to assess if this differs by sex. A number of studies and surveys of public opinion, predominantly from the United States, suggest that the majority of individuals not only want more women in legislatures (Dolan, 2014, Dolan and Sanbonmatsu, 2009; Sanbonmatsu, 2003; Simmons, 2001), but that there is a significant difference by sex in terms of support for this idea (Cook, 1998; Sanbonmatsu, 2003). Based on this we put forward the following hypothesis: 
$H_{1}$ - Women are more likely than men to believe that there ought to be more women in political legislatures.

Second we examine whether, among those who do support a descriptive increase, the proportion of individuals holding the two broad positions discussed above differs by sex. Our initial focus is on those individuals who support the descriptive representation of women but don't believe women better represent women than men - the justice-plus rationale. Our expectation is that such attitudes will be predominantly held by men. This might be for two main reasons. Firstly, men's interests are not as clearly defined as women's interests, either academically or pas a wider popular notion. Contrasting men's interests to the debate around women's interests, Rainbow Murray writes,

'the substantive representation of men attracts little public or scholarly attention. Because men are the dominant group, it is taken as a given that their interests will be understood and defended adequately by legislators. Men's descriptive overrepresentation has triggered complacency concerning their substantive and symbolic representation. Men's interests have not been subjected to the same intense scrutiny and debate and are less clearly defined. Yet, just as "women's interests" are heterogeneous, men also have diverse, gender-specific interests that may not always be represented adequately by a male-dominated legislature' $(2014$, p.528).

Secondly, as the dominant political group, men themselves are perhaps less likely to have had cause to view politics in terms of their own substantive representation. Rather, they might instead view politics through the lens of a seemingly rationalized partisanship and ideology, 
thinking about politics as something that is not tied to their own personal gender identity or other characteristics (Sapiro, 1983). There is some evidence to support this contention, with Robert Johns et al. summarizing this literature as providing 'indirect support for the notion that a social identity account of partisanship is likely to be more accurate for women'. (Johns et al., 2011, p.197). Based on this, we generate the following hypothesis:

$\mathrm{H}_{2}$ - Those who believe that there ought to be more women elected to political legislatures but women are no better at representing women's interests than men (a justice-plus rationale) are more likely to be men than women.

Third, we examine the inverse of $\mathrm{H}_{2}$ : whether, among those who do support a descriptive increase, are women more likely than men to hold the view that there is a link between DRW and SRW, or vice versa? As noted above, a plausible explanation might be that we are all intuitive believers in the link between descriptive and substantive representation based on our own lived experience, but men, as the dominant group in political institutions, have not had to reflect on their own substantive representation in the same way, or at the same rate, as women. As such, men might be oblivious to the fact that there might be such a link in this particular case. Women, on the other hand, women might be keenly aware of it - or at least keenly waiting in anticipation of it. It could equally be the case that women hold a belief in the link between DRW and SRW as a result of their past perceptions of male legislators' behaviour. On this basis, we generate the following hypothesis;

$H_{3 a}$ - Amongst those who believe that there ought to be more women elected to political legislatures, women are more likely to hold the belief that women are better at representing women's interests than men. 
Alternatively, it also seems plausible that no-one has a default belief that members of a social group are better at representing the interests of that social group than anyone else. People might believe, for example, that they themselves are best represented by the content of a political ideology and that this ideology can in turn be represented by anyone regardless of their social characteristics. In such a case, we would expect no sex differences at all. As a result, our fourth and final hypothesis is as follows.

\begin{abstract}
$H_{3 b}$ - Amongst those who believe that there ought to be more women elected to political legislatures, neither men nor women believe that women are better at representing women's interests than men.
\end{abstract}

\title{
Data and Methods
}

We use individual-level data from the 2015 Northern Ireland Election survey to examine public attitudes to women's representation. The dataset contains the individual responses of a representative sample of 1800 electors across eighteen Northern Irish parliamentary constituencies to a range of electoral, political and social questions asked within six weeks of the 2015 UK General Election. Northern Irish politics has seen a surge of interest in the representation of women in recent years, with interest peaking following the election of the first ever woman First Minister of Northern Ireland, Arlene Foster of the Democratic Unionist Party (DUP), in January 2016. Her election came after a mixed 18 years following the Good Friday Agreement in which the inclusion of women in Northern Irish politics failed to meet the goals laid out in the Agreement itself. During that time, the numbers of women in the Northern Ireland Assembly never progressed beyond 20 per cent (Braniff and Whiting, 
2015). ${ }^{4}$ Additionally, in 2015 the Assembly and Executive Review Committee Report on Women in Politics and the Northern Ireland Assembly, set up to explore the question of women's involvement in Northern Irish politics as a whole, made a number of recommendations to political parties, including that they consider implementing measures designed to increase the numbers of women candidates they put forward (2015, p.2). Given this, the issue of women's representation was prominent at the time of the election.

To address our hypotheses, we focus on individual responses to two statements asked in the 2015 Northern Ireland General Election Survey. The first statement examines public support for an increase in the DRW in political institutions $\left(\mathrm{H}_{1}\right)$ : 'There ought to be more women MPs and women elected to the Northern Ireland Assembly'. Through an analysis of responses to this statement, we model the profile of overall support for an increase in DRW and determine whether there is a sex effect after controlling for other predictor variables and established controls. We use this statement as the dependent variable - combining the strongly agree and agree categories - and specify a logistic regression model of support for an increase in DRW and report probabilities along with the conventional betas (log odds units) to aid interpretation of the results. ${ }^{5}$

4 An interesting question is whether attitudes vary dependent on the number of women already in office. If cross-national data was available from a range of countries with sufficient variation in this regard, this could be tested using hierarchical models. Sadly, to the best of our knowledge no such data currently exists.

${ }^{5}$ We combine the two categories for simplicity. Our later model (multinomial logit) combines these categories out of necessity because of the small sample sizes in some of the categories so we felt that similar categorisations of the dependent variable should be used throughout the paper. However, for brevity, we have modelled the data using an ordinal scale and find no differences in the findings or in the significance of key variables. These results are available on request. 
The second statement - 'Women are better placed than men to represent women's interests in politics' - addresses individual attitudes to SRW. ${ }^{6}$ First, in order to test $\mathrm{H}_{2}$, we examine those individuals who are supportive of an increase in DRW but do not feel that women are better than men at representing women (i.e. that there is a link between increased DRW and the quality of SRW). We examine individuals who hold this view first descriptively and then analytically. We use a binomial logistic regression analysis to not only profile their sociodemographic and political attributes, but more importantly, determine whether men are more likely to advocate this justice-plus rationale than women, testing $\mathrm{H}_{2}$.

To test hypotheses $\mathrm{H}_{3 \mathrm{a}}$ and $\mathrm{H}_{3 \mathrm{~b}}$ we establish whether, among those who do support a descriptive increase, women are more likely than men to believe that women are better at representing women's interests than men. Using these data, we can unpack individual support for the increased DRW and examine the relationship between this view and belief in a link between DRW and SRW. Further, we can compare individuals holding these views with those who support descriptive increases without believing that descriptive and substantive representation are linked in the case of women (justice-plus).

Two other categories with relatively small sample sizes are also examined for completeness those individuals who are anti- or indifferent to an increase in DRW and who do not link DRW and SRW, and those individuals who strongly agree or agree that women best represent women's interests but don't agree that there is any need to increase the numbers of women in political institutions. ${ }^{7}$ A somewhat larger sample of 403 individuals make-up the fifth

\footnotetext{
${ }^{6}$ For both questions, individual responses are recorded on a Likert scale from 1-5 where $1=$ Strongly agree and $5=$ Strongly disagree.

${ }^{7}$ The anti/indifferent category contains 83 individuals who a) strongly disagreed or disagreed with both statements; b) strongly disagreed with one statement and was indifferent (responded neither agree nor disagree) with the other. The category containing those who feel
} 
category for those who expressed indifference (neither agree nor disagree) when responding to both statements.

Following a descriptive analysis of the data, we use a multinomial regression analysis where individuals holding justice-plus attitudes are used as the reference category. From this we seek to establish whether women are more likely than men to believe that there should be an increase in DRW and that an increase in DRW results in better SRW $\left(\mathrm{H}_{3 \mathrm{a}}\right)$, compared to those with justice-plus attitudes (i.e. there should be an increase in DRW, but this will not result in any change in SRW), or whether there is no difference in the distribution of these attitudes by $\operatorname{sex}\left(\mathrm{H}_{3 b}\right)$.

Both the logistic and multinomial models include conventional socio-demographic predictors and controls from the survey - sex, age, education, household status, class, working status and frequency of church attendance ${ }^{8}$ - as well as a number of political variables including left-right ideology, political identification and political interest. ${ }^{9}$ In the Northern Irish context, Unionism refers to a political ideology and culture that supports the continuation and preservation of Northern Ireland within the United Kingdom whereas Nationalists seek an

that women are better at representing women's interests comprises 146 individuals who strongly agreed or agree with women better at representing women but strongly disagreed or disagreed with more women in political institutions.

${ }^{8} \mathrm{Sex}$ is a dichotomous variable (Reference $=$ Male) as is Two or more children $($ Reference $=$ None and one child) and Married/Living Together where all other categories are the base. We also include a dummy for church attendance at least once a month. Age is a categorical variable where Middle Age 30-44 is the base category, likewise education (Reference = No qualifications) and class (Reference $=$ higher or salariat class) and employment status (set of dummies for not in work categories: retired, student, not working/unemployed, stay at home, other and missing employment) where the base category is in work (full time and part time employment).

${ }^{9}$ Political identification is included to take account of whether individuals think themselves as Unionist (base category), Nationalist, Neither or Not Sure. Political Interest is a dichotomous variable where a lot and a great deal of interest $=1$ with all other categories zero. Left-Right is self-rated and runs on a scale from $0=$ Far Left to $10=$ Far Right. 
end to this political union with the United Kingdom and advocate a 'United Ireland'- the existence of one Ireland combining Northern Ireland and the Republic of Ireland. ${ }^{10}$ We also include attitudinal variables such trust in politicians and whether women are discriminated against in public life. ${ }^{11}$

\section{Do women express greater support for an increase in the descriptive representation of}

\section{women than men?}

Table 1 shows the results of two logistic regression models measuring support for the descriptive representation of women (those who strongly agree and agree with more women MPs and members of the Northern Ireland Assembly as opposed to those who do not). We run two separate logistic models: the first only includes the sex variable to determine whether there is an identifiable sex effect; the second is the full model containing sex and the predictors outlined above. In this model we determine whether any sex effect holds when other predictors are controlled for. For both models, we report the beta coefficients although the magnitudes of these in logistic models are difficult to interpret. To better assess the relative effect of these variables we convert the statistically significant coefficients into predicted probabilities using Clarify (Tomz, Wittenberg and King 2003). ${ }^{12}$ These are also

${ }^{10}$ Unionists are predominantly Protestants while Nationalists are overwhelmingly Roman Catholic. There is some overlap but generally this is the case. To avoid any correlation (in excess of 0.7 in our data), we include these political identification variables but not religion. However, as noted above we include church attendance to measure religious activity.

${ }^{11}$ Trust in politicians is a dichotomous variable - where don't trust politicians has a value of one and trust is the base category. The statement 'there is discrimination against women in public life' is on a Likert scale where $1=$ Strongly disagree and $5=$ Strongly agree. This is treated as a continuous variable and it is centered around the grand mean to ease interpretation of the parameter estimates. The models below include an interaction between women and discrimination against women in public life. Centering is applicable here because it reduces any correlation (which was 0.20 and well within acceptable bounds) between the multiplicative term and its component variables.

${ }^{12} \mathrm{We}$ calculate the probability of supporting the descriptive representation of women when each significant predictor is varied from its minimum to maximum while simultaneously holding continuous predictor variables at their mean values and at zero for dummy variables formed from multiple category variables. 
shown in Table 1. Finally, we report a number of model fit statistics - Log Likelihood and Akaike Information Criterion - at different stages of the modelling process to assess the extent to which the model has improved following the introduction of additional predictors.

Model 1 examines whether public support for an increase in the descriptive representation of women is greater among women than men. The evidence suggests that this is clearly the case, with women 2.9 times more likely to support an increase in DRW than men. The predicted probabilities also suggest that sex has a sizeable impact. To aid interpretation, we multiply the calculated probabilities by 100 . The probability among women of supporting descriptive representation for women increases by twenty-four points.

\section{Insert Table 1}

But does this sex effect hold when other predictors of descriptive representation are added to the model? The evidence presented in Table 2 suggests that it does, offering descriptive support for $\mathrm{H}_{1}$. Not only does the sex variable remain positive and significant but it still exerts a large effect despite the inclusion of additional variables - the probability of support among women for more women in political legislatures increases by seventeen points. Apart from evidence of a sex effect, those individuals that attend church once a month, have secondary level or below education qualifications, who are married, and in the 45-59 age range are all supportive of an increase in the descriptive representation of women. For those individuals that are not in work and stay at home $-97.6 \%$ of whom are women in this sample - the probability of supporting greater DRW increases by fifteen points. Conversely, those who identify politically as neither Unionist nor Nationalist are less likely to support increases in the descriptive representation for women. Individuals who lack interest in politics exhibit a 
similar response - among the politically uninterested the probability of support for more women in political legislatures lowers by eight points. Far and away the largest effect on support for an increase in DRW comes from holding the belief that women are discriminated against in public life. Among those who agree that women are discriminated against, the probability of supporting greater DRW increases by sixty points. But women who agreed that women are discriminated against in public life - which we measure using an interaction effect - were not significantly more likely to be supportive of an increase in DRW than men who felt the same way.

\section{Are women who support an increase in DRW more likely to also believe in a link between DRW and SRW than men?}

To examine whether women are more likely than men to hold the view that there is a link between DRW and SRW, and descriptively test $\mathrm{H}_{3 \mathrm{a}}$, it is necessary to take account of a number of different attitudinal profiles. As stated earlier, we placed individuals into five categories - unsure, anti- and indifferent, supportive of substantive representation but not DRW, and the two rationales of most interest to us, justice-plus and those who both support an increase in descriptive representation of women and believe in a link between DRW and SRW. Table 2 compares the socio-economic and political profile of these five groups versus the wider population. Those individuals who are supportive of a descriptive increase and believe that increased DRW results in better SRW tend overwhelmingly to be female, working class, have educational qualifications to only the secondary level or below, are those who stay at home, are married and/or live together, and are in part time work. They are more likely to be Nationalists and have lower levels of political interest than average. By contrast, individuals who express the justice-plus rationale seem to have two distinct socio-economic profiles. Above all they are more likely to male and married and/or living together with their 
partner. Additionally, membership of this group is also higher among both young people aged 18-29 and those from the 45-59 age category. A similarly unclear pattern exists for education, class, and working status. Those who advocate a justice-plus rationale tend to be overrepresented among both those with degrees and no qualifications, the higher or salariat class, the working class, those in full-time employment, and those who stay at home. Their political profile, however, is far clearer. They are more likely to be Unionists and slightly more politically interested than average. Descriptively, this evidence offers initial support for $\mathrm{H}_{2}$ and $\mathrm{H}_{3 a}$

Insert Table 2

The remaining three groups are of less interest in terms of the focus of the paper but nonetheless exhibit distinctive socio-demographic and political profiles. As might be expected, those who express anti- or indifferent feelings to both the descriptive and substantive representation of women tend to be over-represented among males, those aged 65 and over, retired individuals, those with no qualifications, those who attend church once a month, not working or unemployed (and also in full-time employment), and the working class. We should be wary of the low sample size, but it is clear that these people are more likely to be Unionists and have higher than average distrust of politicians. Like the anti- and indifferent group, those who are unsure also tend to be male, from older age groups and in full time employment. However, this group is over-represented among the middle classes and those with post-secondary qualifications. They tend to be politically interested but are more likely to be Unionist or Nationalist than the wider population. Our data suggests that those individuals who agree that women better represent women's interests but do not support the statement that there ought to be an increase in DRW also has a unique socio-demographic 
profile. Interestingly, people holding these attitudes tend to be female, in full-time work, middle aged, middle class and highly educated. There is also some over-representation among those who are not working or unemployed, while those that hold this view are more likely to be Nationalist or neither Nationalist nor Unionist and exhibit slightly higher levels of political interest than the wider population.

In summary, individual responses to the two survey statements concerning descriptive and substantive representation can be categorised into five distinct types. Individual members of these categories displayed distinctive socio-economic and political profiles. The descriptive evidence suggests that women rather than men are more likely to hold the view that there is a link between DRW and SRW, offering initial support for $\mathrm{H}_{3 \mathrm{a}}$ and allowing us to reject $\mathrm{H}_{3 \mathrm{~b}}$. Among those advocating the justice-plus rationale, the split is more even between men and women with the former tending to be more over-represented of the two sexes. But is the descriptive evidence of a sex difference borne out when we take account of other predictors?

\section{Modelling justice-plus and substantive rationales}

Building on the descriptive evidence presented above, we proceed by specifying a series of multivariate models to more rigorously address our remaining hypotheses $\left(\mathrm{H}_{2}, \mathrm{H}_{3 \mathrm{a}}\right.$ and $\left.\mathrm{H}_{3 b}\right)$. Initially, we run a binomial logistic regression to contrast those holding justice-plus rationales against all other categories. Model A of Table 3 reports the results of this logistic regression. Model B contrasts those who support an increase in DRW and the view that DRW improves SRW with those who are unsure, anti-, and indifferent, and those who are supportive of the idea that DRW and DRW are linked without agreeing that DRW ought to be increased 
against those holding the justice-plus rationale using a multinomial logistic regression model. $^{13}$

Looking first at the comparison of those individuals who expressed support for the justiceplus rationale against all other individual attitudes combined (first column in Table 3, Model A), the results indicate that, as expected, men are significantly more likely to support this position than women $\left(\mathrm{H}_{2}\right)$. Indeed, being a woman lowers the likelihood of supporting the justice-plus rationale as opposed to alternative attitudes by three points. Apart from evidence of a sex effect, women who agree that women are discriminated in public life are significantly less likely to support descriptive representation for women in isolation - for this group, the probability of advocating a justice-plus rationale reduces by twelve points.

\section{Insert Table 3}

Turning to examine support for the remaining attitudinal positions compared against the justice-plus rationale (the other three columns in Table 3) leads to clear conclusions that directly address our key hypothesis $\left(\mathrm{H}_{3 \mathrm{a}}\right.$ and $\left.\mathrm{H}_{3 \mathrm{~b}}\right)$. Relative to other attitudinal positions, amongst those who believe that there ought to be more women elected to political legislatures, women are significantly more likely to hold the belief that women are better at representing women's interests than men. This finding provides unequivocal support for hypothesis $\left(\mathrm{H}_{3 \mathrm{a}}\right)$. Indeed, being a woman increases the probability of supporting this consequentialist position by a sizeable 21 points (see Figure 1). Individuals who agree that women are discriminated in public life are also significantly more likely hold a belief in the

\footnotetext{
${ }^{13}$ Here we test for Independence of Irrelevant Alternatives (IIA) using both the Hausman and Small-Hsiao test - none of the tests reject the $\mathrm{H}_{0}$ that IIA holds. These findings suggest that a multinomial regression is an appropriate model to address the hypotheses outlined above.
} 
link between descriptive and substantive representation - the probability increases by 60 points and has by far the biggest impact of any variable we include.

\section{Insert Figure 1}

When compared against the justice-plus rationale, those who see a link between increased DRW and better SRW were significantly more likely to either have secondary or postsecondary qualifications as opposed to no educational qualifications. They were also found to have an increased likelihood of self-identifying as a Nationalist in the Northern Irish context. But even when controlling for all these predictors, there is clear evidence of a sex effect. Turning to the other attitudinal positions, when compared with the justice-plus rationale, there is no evidence of a difference by sex and in all three cases individuals are significantly less likely to agree that women are discriminated in public life. Among those who are antiand indifferent, there is some suggestion that this view is not shared by women (as illustrated by the positive coefficient), but given the small sample size we should be wary of overstating the implications of this finding.

\section{Conclusion}

This paper has offered the first attempt in the literature to date to unpack the rationales that might be behind individual-level support for the idea that there ought to be more women present in political institutions. We began by outlining two distinct rationales that might be held regarding any increase in the numbers of women in political institutions - the

substantive position that sees an increase in DRW as important in bringing about a subsequent improvement in SRW, or the justice-plus position that sees an increase in DRW as important for reasons of justice or other symbolic benefits. Exploring four key hypotheses, 
we descriptively found that women are more likely than men to support an increase in DRW, providing evidence for $\mathrm{H}_{1}$. Moving to multivariate analyses, we found that women were more likely to hold both the view that an increase in DRW was desirable and that such an increase would improve the representation of women's political interests (SRW). Conversely, men were found to be more likely to support an increase in DRW but not relate DRW to SRW in any way - the justice-plus rationale. This offers support for $\mathrm{H}_{2}$ and $\mathrm{H}_{3 \mathrm{a}}$, respectively, and no support for $\mathrm{H}_{3 \mathrm{~b}}$ which posited that there might be no sex difference in the distribution of these different attitudes.

Our findings have clear implications for those engaged in trying to increase the numbers of women in political institutions. The evidence we present in this paper suggests that men and women think about the under-representation of women in distinct ways. When women agree that there ought to be greater DRW in politics, we can infer that they do so in additional anticipation of the subsequent positive impact this will have on SRW. In other words, women seem to want more women in politics to some extent because they will represent women's interests better than men. On the other hand, men appear to support increases in DRW for reasons unrelated to SRW, reasons we collectively refer to as the justice-plus rationale. There is clear room for future research into the underpinnings of men and women's attitudes towards issues of gender (in)equality and how these should be resolved (Lovenduski 2012). Such research should inform those involved in the practicalities of convincing voters that the under-representation of women is something that deserves their attention.

Finally, our results raise normative questions regarding the treatment of those women who do make it into elected political office. If women value an increase in the DRW based on the anticipated benefits this will bring in terms of improved SRW, does this mean that these new 
women legislators, or prospective women candidates, are being assessed on an extra criterion that their male colleagues are not? As Joni Lovenduski writes, 'the representation of women in political decision making is vital not because it will necessarily make a difference for women, though it often does, but because justice demands it. Equal representation should be taken for granted, part of the institutional fabric. Women should not have to claim political presence on any other basis than justice. To do so puts a special burden of representation on women MPs who become subject to scrutiny and pressure that male politicians largely avoid' (2012, p.699). As of yet, it would appear that the public remain to be persuaded on this point.

\section{References}

Alexander, Amy C. 2012. Change in Women's Descriptive Representation and the Belief in Women's Ability to Govern: A Virtuous Cycle. Politics \& Gender 8: 437-464. Allen, Peter and Paul Cairney. 2015. What We Talk About When We Talk About the Political Class. Political Studies Review. Early View DOI: 10.1111/1478-9302.12092. Allen, Peter; David Cutts, and Rosie Campbell. 2016. Measuring the Quality of Politicians Elected Via Gender Quotas: Are They Any Different? Political Studies 64(1): 143163.

Assembly and Executive Review Committee. 2015. Report on Women in Politics and the Northern Ireland Assembly. Northern Ireland Assembly.

Bicquelet, Aude; Judith Bara and Albert Weale. 2012. Debating Abortion: Deliberative Reciprocity and Parliamentary Advocacy. Political Studies 60(3): 643-667.

Braniff, Máire and Sophie Whiting. 2015. 'There's Just No Point In Having a Token Woman': Gender and Representation in the Democratic Unionist Party in Post-Agreement 
Northern Ireland. Parliamentary Affairs 69 (1): 93-114.

Broockman, David. 2014. Can the Presence of Female Politicians and Candidates Empower Women to Vote or Run for Office? A Regression Discontinuity Approach. Electoral Studies 34 (1): pp.190-204.

Carnes, Nicholas. 2013. White Collar Government. Chicago: University of Chicago Press.

Carroll, Susan (ed.). 2001. The Impact of Women in Public Office. Bloomington: Indiana University Press.

Celis, Karen; Sarah Childs, Johanna Kantola, and Mona Lena Krook. 2008. Rethinking Women's Substantive Representation. Representation 44(2): 99-110.

Celis, Karen and Sarah Childs. 2012. The Substantive Representation of Women: What to Do with Conservative Claims? Political Studies. 60(1): 213-225.

Childs, Sarah. 2004. New Labour's Women MPs: Women Representing Women. Oxford: Routledge.

Childs, Sarah and Mona Lena Krook. 2009. Analysing Women's Substantive Representation: From Critical Mass to Critical Actors. Government and Opposition 44(2): 125-145.

Clayton, Amanda. 2014. Women's Political Engagement under Quota-Mandated Female Representation: Evidence from a Randomized Policy Experiment. Comparative Political Studies Online First: 1-36.

Cook, Elizabeth Adell. 1998. Voter reaction to women candidates. In Women and Elective Office, pp.56-72, New York: Oxford University Press.

Cowell-Meyers, Kimberly and Laura Langbein. 2009. Linking women's descriptive and substantive representation in the United States. Politics \& Gender 5(04):491-518.

Dahlerup, Drude. 1988. From a Small to a Large Minority: Women in Scandinavian Politics. Scandinavian Political Studies 11 (4): 275-298.

Dolan, Kathleen 2014. When Does Gender Matter? New York: Oxford University Press. 
Dolan, Kathleen and Kira Sabonmatsu. 2009. Gender stereotypes and attitudes toward gender balance in government. American Politics Research 37(3): 409-428.

Hacker, Jacob and Paul Pierson. 2011. Winner-Take-All Politics. New York: Simon \& Schuster.

Johns, Robert; Kristi Winters and Rosie Campbell. 2011. My Heart Says One Thing but My Head Says Another? Men, Women, and the Psychology of Partisanship in Britain. Politics \& Gender 7(2): 193-222.

Lovenduski, Joni. 2005. Feminizing Politics. London: Polity.

Lovenduski, Joni. 2012. Feminizing British Politics. The Political Quarterly 83(4): 697-702. Lovenduski, Joni, and Pippa Norris, eds. 1993. Gender and Party Politics. London: Sage. Mackay, Fiona. 2008. 'Thick' Conceptions of Substantive Representation: Women, Gender and Political Institutions. Representation 44(2):125-139.

Mansbridge, Jane. 1999. Should Blacks Represent Blacks and Women Represent Women? A Contingent "Yes". The Journal of Politics 61 (3): 628-657.

Murray, Rainbow. 2010. Second Among Unequals? A Study of Whether France's 'Quota Women' are Up to the Job. Politics \& Gender 6(1): 93-118.

Murray, Rainbow. 2014. Quotas for Men: Reframing Gender Quotas as a Means of Improving Representation for All. American Political Science Review. 108(3): 520532.

Penny, Laurie. 2015. If Men Got Pregnant, Abortion Would Be Legal Everywhere. New Statesman. 4 December 2015, available online http://www.newstatesman.com/politics/feminism/2015/12/if-men-got-pregnantabortion-would-be-legal-everywhere [last accessed 2015-01-28].

Phillips, Anne. 1995. The Politics of Presence: Political Representation of Gender Race and Ethnicity. Oxford: Oxford University Press. 
Phillips, Anne. 2012. Representation and Inclusion. Politics and Gender 8 (4): 512-518.

Pitkin, Hanna Fenichel. 1973. The Concept of Representation. Berkeley: University of California Press.

Reingold, Beth. 2000. Representing Women: Sex, Gender, and Legislative Behavior in Arizona and California. Chapel Hill, NC: University of North Carolina Press.

Sanbonmatsu, Kira. 2003. Gender-Related Political Knowledge and the Descriptive Representation of Women. Political Behavior 25(4): 367-388.

Sapiro, Virginia. 1983. The Political Integration of Women: Roles, Socialization, and Politics. Chicago: University of Illinois Press.

Simmons, Wendy. 2001. Majority of Americans Say More Women in Political Office Would be Positive for Country. Gallup Poll Monthly, January: 7-8.

Swers, Michele. 1998. Are Congresswomen More Likely to Vote for Women's Issue Bills Than Their Male Colleagues? Legislative Studies Quarterly 23: 435-448.

Thomas, Sue and Susan Welch. 1991. The Impact of Gender on Activities and Priorities of State Legislators. The Western Political Quarterly 44(2): 445-456.

Tomz, Michael, Jason Wittenberg and Gary King. 2003. CLARIFY: Software for Interpreting and Presenting Statistical Results. Harvard University, Department of Government, Cambridge, MA.

Vega, Arturo and Juanita M. Firestone. 1995. The Effects of Gender on Congressional Behavior and the Substantive Representation of Women. Legislative Studies Quarterly 20(2): 213-222.

Young, Iris Marion. 2001. Inclusion and Democracy. Oxford: Oxford University Press. 


\section{Tables}

Table 1: Logistic Regression Model of Public Support for Descriptive Representation

\begin{tabular}{|c|c|c|c|c|c|}
\hline \multirow[t]{2}{*}{ Variables } & \multicolumn{2}{|c|}{$\begin{array}{l}\text { Model 1: Descriptive } \\
\text { Representation }\end{array}$} & \multicolumn{3}{|c|}{$\begin{array}{l}\text { Model 2: Descriptive } \\
\text { Representation }\end{array}$} \\
\hline & SE & Probabilities & $\beta$ & SE & Probabilities \\
\hline Constant & $0.09 \quad 0.07$ & - & -0.51 & 0.28 & - \\
\hline \multicolumn{6}{|l|}{ Sex } \\
\hline Female & $1.08 * 0.10$ & 0.24 & $0.77 *$ & 0.11 & 0.17 \\
\hline \multicolumn{6}{|l|}{ Household Status } \\
\hline Married/LT & & & $0.37 *$ & 0.13 & 0.08 \\
\hline \multicolumn{6}{|l|}{ Children } \\
\hline Two or More & & & -0.01 & 0.16 & - \\
\hline \multicolumn{6}{|l|}{ Age } \\
\hline Young Age 18-29 & & & -0.15 & 0.19 & - \\
\hline Mid/Older Age 45-59 & & & $0.49^{*}$ & 0.16 & 0.10 \\
\hline Old Age 60 plus & & & 0.38 & 0.24 & - \\
\hline Missing Age & & & 0.14 & 0.29 & - \\
\hline \multicolumn{6}{|l|}{ Education } \\
\hline Degree & & & 0.48 & 0.26 & - \\
\hline Post-Secondary & & & 0.30 & 0.19 & - \\
\hline Secondary and Below & & & $0.51 *$ & 0.17 & 0.11 \\
\hline Missing Education & & & 0.10 & 0.35 & - \\
\hline \multicolumn{6}{|l|}{ Class } \\
\hline Middle Class & & & 0.12 & 0.18 & - \\
\hline Working Class & & & 0.37 & 0.20 & - \\
\hline Missing Class & & & 0.02 & 0.24 & - \\
\hline \multicolumn{6}{|l|}{ Attend Church } \\
\hline At least Once a Month & & & $0.25^{*}$ & 0.12 & 0.05 \\
\hline Employment & & & & & \\
\hline
\end{tabular}




\begin{tabular}{|c|c|c|c|}
\hline Not Working/Unemployed & & $-0.23 \quad 0.19$ & - \\
\hline Retired & & $-0.16 \quad 0.24$ & - \\
\hline Long Term Ill & & $-0.12 \quad 0.30$ & - \\
\hline Student & & $0.68 \quad 0.37$ & - \\
\hline Stay at Home & & $0.78 * 0.25$ & 0.15 \\
\hline Other Employment & & $\begin{array}{ll}0.04 & 0.50\end{array}$ & - \\
\hline Missing Employment & & $-0.19 \quad 0.36$ & - \\
\hline \multicolumn{4}{|l|}{ Political } \\
\hline Nationalist & & $0.23 \quad 0.17$ & - \\
\hline Neither & & $-0.45 * 0.15$ & -0.10 \\
\hline Not Sure Either & & $-0.35 \quad 0.22$ & - \\
\hline \multicolumn{4}{|l|}{ Interest in Politics } \\
\hline A lot + Great Deal & & $-0.34 * 0.16$ & -0.08 \\
\hline \multicolumn{4}{|l|}{ Trust Politicians } \\
\hline Don't Trust Politicians & & $-0.55 \quad 0.35$ & - \\
\hline \multicolumn{4}{|l|}{ Self-Rated Ideology } \\
\hline Left-Right & & $0.06 \quad 0.04$ & - \\
\hline \multicolumn{4}{|l|}{ Discrimination } \\
\hline Women in Public Life & & $0.76^{*} \quad 0.10$ & 0.60 \\
\hline Female*Women in Pub Life & & $-0.14 \quad 0.13$ & - \\
\hline \multicolumn{4}{|l|}{ Model Fit } \\
\hline LR Chi-Square & $110.70^{*}$ & \multicolumn{2}{|c|}{$259.22 *$} \\
\hline Log Likelihood & -1108.95 & \multicolumn{2}{|c|}{-991.47} \\
\hline AIC & 2221.90 & \multicolumn{2}{|c|}{2044.94} \\
\hline $\mathbf{N}$ & 1800 & \multicolumn{2}{|c|}{1800} \\
\hline
\end{tabular}

*Significant $<0.05$. Additional model fit statistics - Model 1: McFadden's $\mathrm{R}^{2}=0.05$. Model 2: McFadden's $\mathrm{R}^{2}=0.15$. 
Table 2. Socio-Economic and Political Profile of Attitudes to the Representation and Women in Politics

\begin{tabular}{|l|c|c|c|c|c|c|}
\hline $\begin{array}{l}\text { Socio-Economic } \\
\text { Profile }\end{array}$ & $\begin{array}{c}\text { Anti \& } \\
\text { Indifferent } \\
\%\end{array}$ & $\begin{array}{c}\text { Justice- } \\
\text { Plus } \\
\%\end{array}$ & $\begin{array}{c}\text { Substantive } \\
\%\end{array}$ & $\begin{array}{c}\text { No Justice + \& } \\
\text { Yes } \\
\text { Substantive } \\
\%\end{array}$ & $\begin{array}{c}\text { Unsure } \\
\%\end{array}$ & $\begin{array}{c}\text { Overall } \\
\text { Sample } \\
\%\end{array}$ \\
\hline Sex & & & & & & \\
\hline Female & 32.5 & 48.2 & 64.4 & 58.9 & 33.7 & 52.4 \\
\hline Male & 67.5 & 51.8 & 35.6 & 41.1 & 66.3 & 47.6 \\
\hline Household Status & & & & & & \\
\hline $\begin{array}{l}\text { Married/Living } \\
\text { Together }\end{array}$ & 56.6 & 64.5 & 63.2 & 54.8 & 51.4 & 59.7 \\
\hline Children & & & & & & \\
\hline No Children & 65.1 & 60.9 & 61.5 & 60.3 & 69.2 & 63.2 \\
\hline One Child & 16.8 & 14.7 & 16.5 & 13.0 & 15.9 & 15.8 \\
\hline Two or More & 18.1 & 24.4 & 22.0 & 26.7 & 14.9 & 21.0 \\
\hline Age & & & & & & \\
\hline Young Age 18-29 & 9.6 & 17.8 & 14.9 & 13.7 & 19.4 & 15.9 \\
\hline Middle Age 30-44 & 26.5 & 30.5 & 29.1 & 34.9 & 29.3 & 29.7 \\
\hline Mid/Older Age 45-59 & 19.3 & 27.4 & 26.3 & 26.0 & 19.1 & 24.4 \\
\hline Old Age 60 plus & 39.8 & 20.3 & 24.0 & 22.6 & 25.3 & 24.5 \\
\hline Missing Age & 4.8 & 4.1 & 5.7 & 2.7 & 6.9 & 5.5 \\
\hline Education & & & & & & \\
\hline Degree & 8.4 & 17.3 & 10.5 & 19.2 & 9.4 & 11.6 \\
\hline Post-Secondary & 24.1 & 29.4 & 34.0 & 24.7 & 38.5 & 33.3 \\
\hline Secondary and Below & 24.1 & 26.4 & 33.2 & 28.1 & 22.6 & 29.2 \\
\hline No Qualifications & 38.6 & 24.9 & 18.8 & 24.7 & 23.3 & 21.9 \\
\hline Missing Education & 4.8 & 2.0 & 3.5 & 3.4 & 6.2 & 4.0 \\
\hline Social Class & & & & & & \\
\hline Higher Class/Prof & 8.5 & 20.3 & 16.2 & 24.6 & 17.4 & 17.2 \\
\hline Middle Class & 31.3 & 28.9 & 31.0 & 37.0 & 35.0 & 32.2 \\
\hline
\end{tabular}




\begin{tabular}{|l|c|c|c|c|c|c|}
\hline Working Class & 36.1 & 33.5 & 33.6 & 23.3 & 24.8 & 30.9 \\
\hline Attend Church & & & & & & \\
\hline At least Once a Month & 44.6 & 38.6 & 40.7 & 32.9 & 28.0 & 37.2 \\
\hline Employment & & & & & & \\
\hline Full Time Work & 41.0 & 42.1 & 31.8 & 45.2 & 41.2 & 36.6 \\
\hline Part Time Work & 4.8 & 11.2 & 13.7 & 4.8 & 7.2 & 10.8 \\
\hline Not Working/Unemp & 12.0 & 8.6 & 9.1 & 15.8 & 11.7 & 10.3 \\
\hline Retired & 22.9 & 14.7 & 19.1 & 21.2 & 20.3 & 19.2 \\
\hline Long Term Ill & 8.4 & 3.6 & 2.6 & 0.7 & 4.2 & 3.2 \\
\hline Student & 1.2 & 4.1 & 3.7 & 2.1 & 3.5 & 3.4 \\
\hline Stay at Home & 3.6 & 14.2 & 15.8 & 4.8 & 4.2 & 11.6 \\
\hline Other Employment & 1.2 & 0 & 1.3 & 1.4 & 0.7 & 1.1 \\
\hline Missing Employment & 4.8 & 1.5 & 3.0 & 4.1 & 6.9 & 3.9 \\
\hline Political & & & & & & \\
\hline Unionist & 44.6 & 49.2 & 31.7 & 28.1 & 33.0 & 34.2 \\
\hline Nationalist & 32.5 & 16.8 & 31.5 & 31.5 & 14.9 & 26.2 \\
\hline Neither & 20.5 & 22.8 & 31.1 & 40.4 & 39.5 & 32.3 \\
\hline Not Sure Either & 2.4 & 11.2 & 5.7 & 0 & 12.7 & 7.2 \\
\hline Interest in Politics & & & & & & \\
\hline A lot + Great Deal & 32.5 & 16.8 & 13.3 & 16.4 & 16.9 & 15.6 \\
\hline Trust Politicians & & & & & & \\
\hline Don't Trust Politicians & 12.0 & 3.0 & 2.3 & 3.4 & 2.7 & 3.0 \\
\hline N & 83 & 197 & 971 & 146 & 403 & 1800 \\
\hline
\end{tabular}

*Note - In some cases, percentages do not total $100 \%$ because of missing categories (Missing class $-24.1 \%$ Anti/Indifferent; $17.3 \%$ Justice $+; 19.2 \%$ Justice $+\&$ Substantive; $15.1 \%$ No Justice $+\&$ Yes Substantive; $22.8 \%$ Unsure; $19.7 \%$ Overall). **For each attitudinal question, Strongly Agree and Agree have been combined (given a value of 1) with all others responses given a value of zero. 
Table 3: Binomial (Model A) and multinomial logit (Model B) models of attitudinal positions towards the representation of women in politics

\begin{tabular}{|c|c|c|c|c|c|c|c|c|c|c|}
\hline \multirow[t]{2}{*}{ Variables } & \multicolumn{2}{|c|}{$\begin{array}{l}\text { Model A } \\
\text { Justice } \\
\text { Plus }\end{array}$} & \multicolumn{2}{|c|}{$\begin{array}{l}\text { Model B } \\
\text { Anti/ } \\
\text { Indifferent }\end{array}$} & \multicolumn{2}{|c|}{$\begin{array}{l}\text { Model B } \\
\text { Unsure }\end{array}$} & \multicolumn{2}{|c|}{$\begin{array}{c}\text { Model B } \\
\text { No J+ Yes } \\
\text { Substantive }\end{array}$} & \multicolumn{2}{|c|}{$\begin{array}{c}\text { Model B } \\
\text { Yes J+ Yes } \\
\text { Substantive }\end{array}$} \\
\hline & $\beta$ & SE & $\beta$ & $\mathrm{SE}$ & $\beta$ & SE & $\beta$ & $\mathrm{SE}$ & & $\mathrm{SE}$ \\
\hline Constant & $-1.50^{*}$ & 0.42 & $-1.93 *$ & 0.77 & $0.90^{*}$ & 0.45 & -0.06 & 0.57 & 0.27 & 0.42 \\
\hline \multicolumn{11}{|l|}{ Sex } \\
\hline Female & $-0.36^{*}$ & 0.17 & 0.21 & 0.37 & -0.32 & 0.20 & 0.12 & 0.25 & $0.73 *$ & 0.18 \\
\hline \multicolumn{11}{|l|}{ Household Status } \\
\hline Married/LT & 0.23 & 0.20 & -0.40 & 0.32 & $-0.44 *$ & 0.21 & -0.47 & 0.26 & -0.08 & 0.19 \\
\hline \multicolumn{11}{|l|}{ Children } \\
\hline Two or More & 0.17 & 0.21 & -0.05 & 0.40 & -0.33 & 0.25 & 0.25 & 0.30 & -0.17 & 0.22 \\
\hline \multicolumn{11}{|l|}{ Age } \\
\hline Young Age 18-29 & 0.36 & 0.28 & -0.82 & 0.55 & -0.28 & 0.31 & -0.71 & 0.39 & -0.34 & 0.28 \\
\hline Mid/Older Age 45-59 & 0.05 & 0.22 & -0.42 & 0.42 & -0.44 & 0.26 & -0.17 & 0.31 & 0.16 & 0.23 \\
\hline Old Age 60 plus & -0.32 & 0.31 & 0.50 & 0.55 & -0.01 & 0.40 & -0.51 & 0.53 & 0.46 & 0.36 \\
\hline Missing Age & -0.24 & 0.41 & 0.14 & 0.72 & 0.25 & 0.47 & -0.65 & 0.69 & 0.28 & 0.43 \\
\hline \multicolumn{11}{|l|}{ Education } \\
\hline Degree & 0.45 & 0.34 & -0.83 & 0.65 & -0.67 & 0.41 & -0.58 & 0.47 & -0.23 & 0.36 \\
\hline Post-Secondary & -0.38 & 0.25 & -0.19 & 0.46 & 0.42 & 0.30 & -0.36 & 0.39 & $0.58 *$ & 0.27 \\
\hline Secondary and Below & -0.40 & 0.24 & -0.06 & 0.42 & 0.10 & 0.29 & -0.05 & 0.35 & $0.67 *$ & 0.26 \\
\hline Missing Education & -0.36 & 0.71 & 0.09 & 0.27 & 0.39 & 0.67 & -0.09 & 0.86 & 0.41 & 0.64 \\
\hline \multicolumn{11}{|l|}{ Class } \\
\hline Middle Class & 0.09 & 0.27 & 0.47 & 0.55 & -0.08 & 0.30 & -0.22 & 0.36 & 0.06 & 0.28 \\
\hline Working Class & 0.32 & 0.29 & 0.47 & 0.58 & -0.48 & 0.33 & $-1.01 *$ & 0.41 & -0.19 & 0.30 \\
\hline Missing Class & 0.04 & 0.35 & 1.18 & 0.66 & -0.08 & 0.41 & -0.71 & 0.51 & -0.12 & 0.37 \\
\hline \multicolumn{11}{|l|}{ Attend Church } \\
\hline At least Once a Month & 0.19 & 0.18 & -0.02 & 0.32 & -0.40 & 0.21 & -0.41 & 0.26 & -0.12 & 0.18 \\
\hline \multicolumn{11}{|l|}{ Employment } \\
\hline Not Working/Unemployed & -0.30 & 0.32 & 0.19 & 0.53 & 0.34 & 0.35 & 0.78 & 0.40 & 0.27 & 0.32 \\
\hline Retired & -0.34 & 0.31 & -0.27 & 0.55 & 0.50 & 0.41 & $1.04 *$ & 0.52 & 0.42 & 0.37 \\
\hline
\end{tabular}




\begin{tabular}{|c|c|c|c|c|c|}
\hline Long Term Ill & $0.05 \quad 0.48$ & $0.06 \quad 0.68$ & $\begin{array}{ll}0.21 & 0.51 \\
\end{array}$ & $0.06 \quad 0.68$ & $\begin{array}{ll}-0.05 & 0.48 \\
\end{array}$ \\
\hline Student & $0.11 \quad 0.51$ & -1.201 .27 & $-0.52 \quad 0.62$ & $-0.04 \quad 0.87$ & $0.29 \quad 0.56$ \\
\hline Stay at Home & $0.35 \quad 0.26$ & $\begin{array}{ll}-1.22 & 0.73 \\
\end{array}$ & $-0.85 * 0.38$ & $\begin{array}{ll}-0.76 & 0.51 \\
\end{array}$ & $\begin{array}{ll}-0.11 & 0.29 \\
\end{array}$ \\
\hline Other Employment & - & $0.14 \quad 0.13$ & $0.14 \quad 0.13$ & $0.16 \quad 0.13$ & $0.15 \quad 0.13$ \\
\hline Missing Employment & -1.110 .83 & $\begin{array}{ll}0.63 & 1.01 \\
\end{array}$ & $1.08 \quad 0.74$ & $1.79 \quad 0.90$ & $1.22 \quad 0.73$ \\
\hline \multicolumn{6}{|l|}{ Political } \\
\hline Nationalist & $-1.14 * 0.23$ & $1.01 * 0.40$ & $0.45 \quad 0.28$ & $1.48 * 0.34$ & $1.33 * 0.25$ \\
\hline Neither & $-0.93 * 0.21$ & $0.48 \quad 0.40$ & $1.10 * 0.23$ & $1.33 * 0.30$ & $0.83 * 0.21$ \\
\hline Not Sure Either & $0.13 \quad 0.28$ & $-1.24 \quad 0.80$ & $0.50 \quad 0.32$ & $-0.15 \quad 0.57$ & $-0.28 \quad 0.30$ \\
\hline \multicolumn{6}{|l|}{ Interest in Politics } \\
\hline A lot + Great Deal & $\begin{array}{ll}-0.03 & 0.22 \\
\end{array}$ & $0.80 * 0.34$ & $0.12 \quad 0.25$ & $0.01 \quad 0.52$ & $-0.19 \quad 0.23$ \\
\hline \multicolumn{6}{|l|}{ Trust Politicians } \\
\hline Don't Trust Politicians & $0.22 \quad 0.44$ & $1.50 * 0.58$ & $\begin{array}{ll}-0.30 & 0.53 \\
\end{array}$ & $\begin{array}{ll}-0.11 & 0.63 \\
\end{array}$ & $\begin{array}{ll}-0.58 & 0.49 \\
\end{array}$ \\
\hline \multicolumn{6}{|l|}{ Self-Rated Ideology } \\
\hline Left-Right & $-0.03 \quad 0.05$ & $\begin{array}{ll}-0.04 & 0.09 \\
\end{array}$ & $-0.02 \quad 0.06$ & $0.06 \quad 0.07$ & $0.07 \quad 0.05$ \\
\hline \multicolumn{6}{|l|}{ Discrimination } \\
\hline Women in Public Life & $0.07 \quad 0.12$ & $-1.18 * 0.22$ & $-0.31 * 0.15$ & $-0.50 * 0.19$ & $0.40 * 0.15$ \\
\hline Female*Women in Pub Life & $-0.32 * 0.16$ & $0.74 * 0.33$ & $0.07 \quad 0.21$ & $0.34 \quad 0.27$ & $\begin{array}{ll}0.05 & 0.19 \\
\end{array}$ \\
\hline \multicolumn{6}{|l|}{ Model Fit } \\
\hline LR Chi-Square & $83.50 *$ & $650.22 *$ & $650.22 *$ & $650.22 *$ & $650.22 *$ \\
\hline Log Likelihood & -583.08 & -1935.29 & -1935.29 & -1935.29 & -1935.29 \\
\hline AIC & 1226.16 & 4118.56 & 4118.56 & 4118.56 & 4118.56 \\
\hline $\mathbf{N}$ & 1800 & 1800 & 1800 & 1800 & 1800 \\
\hline
\end{tabular}

*Significant $<0.05 . *$ Note: Justice-plus is the base category for Model B. 


\section{Figures}

Figure 1: Effects of significant predictors on the probability of supporting an increase in DRW and also believing that increased DRW leads to better SRW

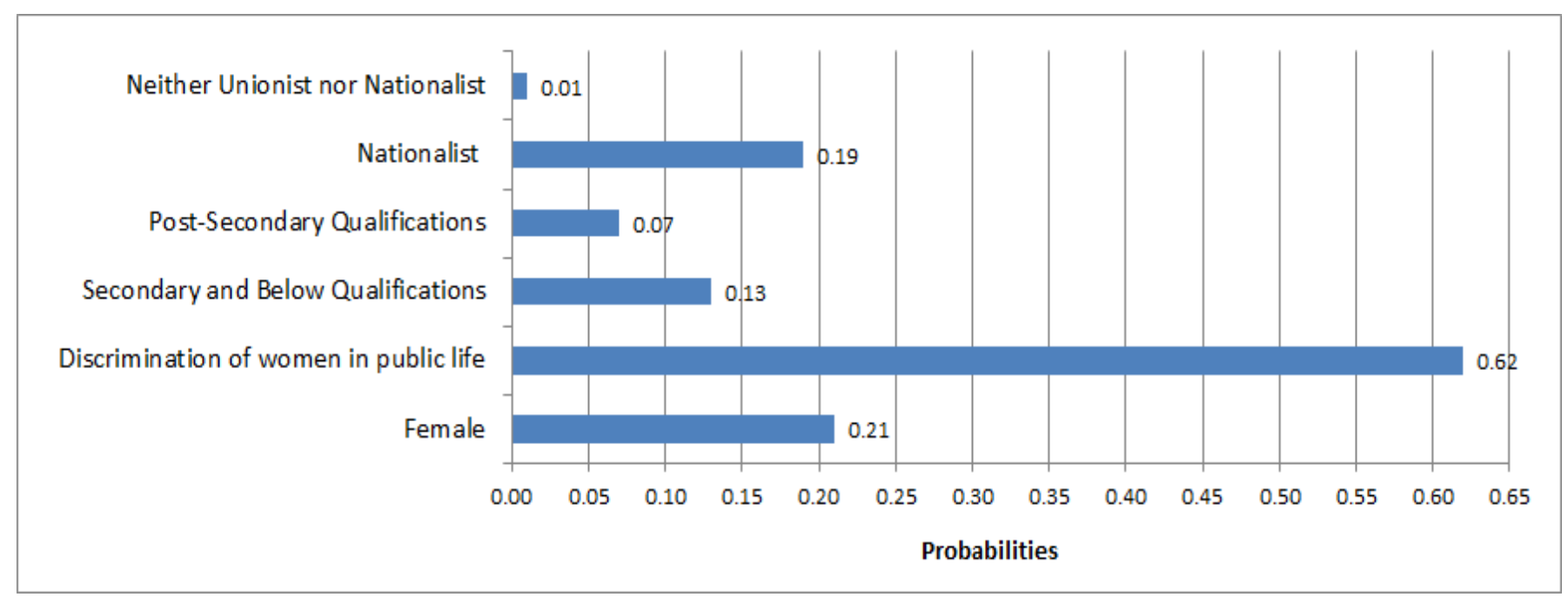

*Predicted probabilities derived from Table 3 where the justice-plus rationale is the base category. 